\title{
Practical Wisdom, Respect and Metaphysics: A Broad Spectrum for Philosophy of Management
}

\section{Wim Vandekerckhove ${ }^{1}$ (D)}

Published online: 29 October 2019

(C) Springer Nature Switzerland AG 2019

\begin{abstract}
In this issue we combine four stand-alone articles with another four articles that form part of a special theme. In doing so, we stretch a very broad spectrum, from micro-level behaviour to metaphysics.
\end{abstract}

In the first article of this issue, Costello (2019) reconsiders Aristotle's Phronesis in a management education setting. In particular, he asks whether we are really teaching wisdom and carefulness when we teach about innovation. Given the current educational policy focus pushes the STEM subjects, and business schools showcase their entrepreneurship hobs, it is timely to ask whether we are cultivating phronesis in future managers?

Drawing on Aristotle, Gadamer, Levinas and Flyvbjerg, the article argues that practical wisdom - knowing how things are and what to do - implies not only knowing why (episteme), knowing how (techne), but also making the right choices (phronesis). Perhaps the ideal description of an entrepreneur is that of an innovator who is successful in making a start-up blossom. Disruptive technology might have skewed our understanding of this ideal somewhat. It is possible that we value disruption for the sake of its disruptiveness. That would fall short of what Aristotle meant with phronesis, which entails deliberation based on values and informed by reflection. AI in healthcare, fintech, gig economy platforms and WeWork-like backlashes make a re-examining of phronesis timely. It is right to be upset about Facebook and Cambridge Analytica, but no one was really surprised it happened: it was bound to happen and still it is unclear how the risk of it happening again is reduced. Regulatory intervention might help us here, sure, but there is also a duty on HE to take a break from celebrating every cowboy-techspin-off. The emerging shift to social entrepreneurship is one that brings hope, yet it is not where the big bucks are. There is however a tricky paradox relating to phronesis in innovation. Costello (2019) points out that Levinas' ethics of responsibility has its foundation in the proximity of the Other. Yet in innovation there is no proximity: consequences are largely unknown and in the future. A recent special issue of this journal (cf. Blok 2018) focuses on responsible innovation, and Costello (2019) takes up insights from that issue.

Wim Vandekerckhove

w.vandekerckhove@greenwich.ac.uk

1 Faculty of Business, University of Greenwich, London, UK 
Costello (2019) describes how phronesis was implemented in a Student Entrepreneurship competition at Galway-Mayo Institute of Technology (GMIT, Ireland), where engineering and business students formed cross-functional teams. From his reflection we can learn that it is not enough to design it into module trajectories. Rather, we need to explicitly draw attention to and for phronesis, notions of 'common good', cross-discipline perceptions and practices of recognition.

In the second article of this issue, Peltonen (2019) leans on the philosophers Plato and Voegelin to argue that modern organisations should seek to re-animate religious symbols and myths of transcendence as devices for open consciousness. Of course, both Plato and Voegelin can be read from a religious theological perspective but the point here is to offer their insights as philosophical approaches to the question of spirituality.

Peltonen (2019) argues that Pato's and Voegelin's transcendental metaphysical reflection on the ordering of the social and the political are relevant to the management of our organisations. Such reflections are important to understand the full bearance of notions we use to organise and manage see for example Shaw's (2019) article in the previous issue on Heraclitus and change management. Process philosophers such as Whitehead also provide accounts of immanent ordering (nature and human institutions) but whereas process theology sees immanent reality shaping the ultimate transcendental reality (forms and God), Plato's and Voegelin's accounts emphasize a participative economy of the human-divine contact, denying the idea that immanent reality can affect transcendent reality. In other words, the phrase 'the sky is the limit' implies that there is indeed a limit, rather than 'anything is possible'. Voegelin would condemn the know-it-all confidence of many managers as a hubris that rejects the natural limits of human reason and politics vis-à-vis a transcendental 'ground' of being.

The article provides a fascinating history of ideas as to why transcendency and spirituality are missing from contemporary organisation and management theory. Could it be that our current-day workplace issues of pollution, mental-health problems and greed are indicators of a shot-through de-sacralisation? Peltonen seems to suggest so. With Voegelin, Peltonen (2019) claims that 'there remains always a longing or craving for the lost union with the divine Beyond, simply because [...] the transcendental realm of Forms is fundamentally real and works all the time in the background of human imagination and existence.'

In this issue, we also include two papers that relate to the micro-level of management. Sekerka and Yacobian (2019) consider discriminatory behaviour as incivility. In a 2016 survey, $62 \%$ of participants said they had experienced rudeness amounting to incivility in the workplace. Sekerka and Yacobian argue that this stems from a mismanaged diversity, i.e. assumptions and implicit biases are not explicitly managed. The article discusses how respect is behavioural but guided by cognitive and affective process, to then offer a model to respond to incivility in a respectful way. Such an approach is needed because employees tend to turn away, become apathic or simply ignore wrongdoing.

Whilst it is easy to understand business contexts as instrumental and motivated through individual achievement, respect must be genuinely owed. Given that is a socio-cultural construct and thus must be collectively established, it is far from evident that it happens in a workplace setting. In other words, in diverse settings such as current-day workplaces, you can expect uncivil behaviours such as rudeness, discrimination or harassment to happen, unless you do something about it. If respect is not reaffirmed and reinforced it remains an after-thought or is completely ignored. In their article, Sekerka and Yacobian (2019) approach respect as a moral response-action, i.e. they focus on the situation in which someone witnesses the disrespectful behaviour of a coworker, and thus has the onus of deciding how to respond. Throughout the article, they use antiMuslimism in a US workplace context as an example. Extant research shows that subtle forms of 
incivility make it more likely that witnesses will not engage in moral-response-action - i.e. they will remain silent or turn away thereby increasing the likelihood of bystander effect - or even side with the perpetrator of the uncivil behaviour.

Sekerka and Yacobian's model mitigates the risk of inaction by supplementing automatic selfregulation (values, traits and virtues that determine first order desires) with deliberate self-regulation (second order desires). Whilst the former supports a desire to act, it is the latter that advances that desire. It is not that we do not want to respect another, but we often lack the ability to endorse and fortify that desire. It is precisely that ability that must be learned and managed. Sekerka and Yacobian (2019) discuss the cognitive (self-efficacy, outcome expectations and norms) and affective (anticipated emotions and affect towards means) dimensions of that ability.

The starting question of Bohl's (2019) article in this issue is: 'As we observe the organisational lifeworld, how do we know if what we observe is in fact leadership?' Bohl offers a fascinating history-of-ideas critique of leader-centric notions of leadership, such as traits/learned approaches, follower approaches and tripod theories. Bohl argues that these perspectives assign responsibility for and results of leadership to the individual. The article then pays attention to process perspectives, which propose a more distributed form of agency. There is of course an extant literature on leadership-as-process, but Bohl's contribution to that lies in how the article reassesses the ontological, epistemological and ethical grounds of these two leadership paradigms.

One could easily think of controversial leaders such as Travis Kalanick (previously Uber) or Adam Neumann (previously WeWork), or for that matter political leaders such as Xi Jinping, Donald Trump, or Boris Johnson, whilst reading Bohl's exposé. Whatever your positions are on these people, notice how the narrative would change depending on whether we take a leader-centric or a process view on leadership. Boris and Xi take different ontological explanations for why they are in leader positions and how leadership exists. In one paradigm 'they've got what it takes'; in the other they are part of the same phenomenon as we are. The same goes for epistemological questions: Donald, fake news, real news and defective or erratic decision-making make impeachment matter but question whether it is a president or a nation that goes on trial - regardless of what you think the outcome of the pending investigations might be.

As Bohl (2019) shows, the ontological and epistemological positions have implications for the ethical dimensions of leadership. For me, that is where Bohl's article really pounds in. From a process perspective, 'when we contemplate leadership, we contemplate the existence and purpose of a group as it relates to facilitating real change'. However, there is no chance of a leader taking up the ethical responsibility we owe each other! Leadership success is facilitated through the engagement of diverse stakeholders. To that end, Bohl (2019) calls for more in-depth reassessment of the epistemological and ethical needs of that process perspective on leadership.

In this issue you will also find four papers that form a Special Theme, skilfully introduced by Marian Eabrasu (2019), an executive editor of this journal. The four papers under this special theme explore philosophical and theological implications of religion in management.

\section{References}

Bohl, K.W. 2019. Leadership as phenomenon: Reassessing the philosophical ground of leadership studies. Philosophy of Management. https://doi.org/10.1007/s40926-019-00116-x.

Blok, V. 2018. Philosophy of innovation: A research agenda (guest editorial). Philosophy of Management 17 (1): $1-5$. 
Costello, G.J. 2019. The philosophy of innovation in management education: a study utilising Aristotle's concept of phronesis. Philosophy of Management. https://oi.org/10.1007/s40926-018-00104-7.

Eabrasu, M. 2019. Gods are still in business. Philosophy of Management 18 (3) [this issue].

Peltonen, T. 2019. Transcendence, consciousness and order: Towards a philosophical spirituality of organization in the footsteps of Plato and Eric Voegelin. Philosophy of Management. https://doi.org/10.1007/s40926-01800105-6.

Sekerka, L., and M.M. Yacobian. 2019. Respect as a moral response to workplace incivility. Philosophy of Management. https://doi.org/10.1007/s40926-019-00113-0.

Shaw, D. 2019. On misunderstanding Heraclitus: the justice of organisation structure. Philosophy of Management 18 (2): $157-167$.

Publisher's Note Springer Nature remains neutral with regard to jurisdictional claims in published maps and institutional affiliations.

Wim Vandekerckhove holds a $\mathrm{PhD}$ in Moral Sciences from Ghent University. He is now Reader in Business Ethics at the University of Greenwich in London, where he is also co-Director of the Centre for Research in Employment and Work (CREW). 